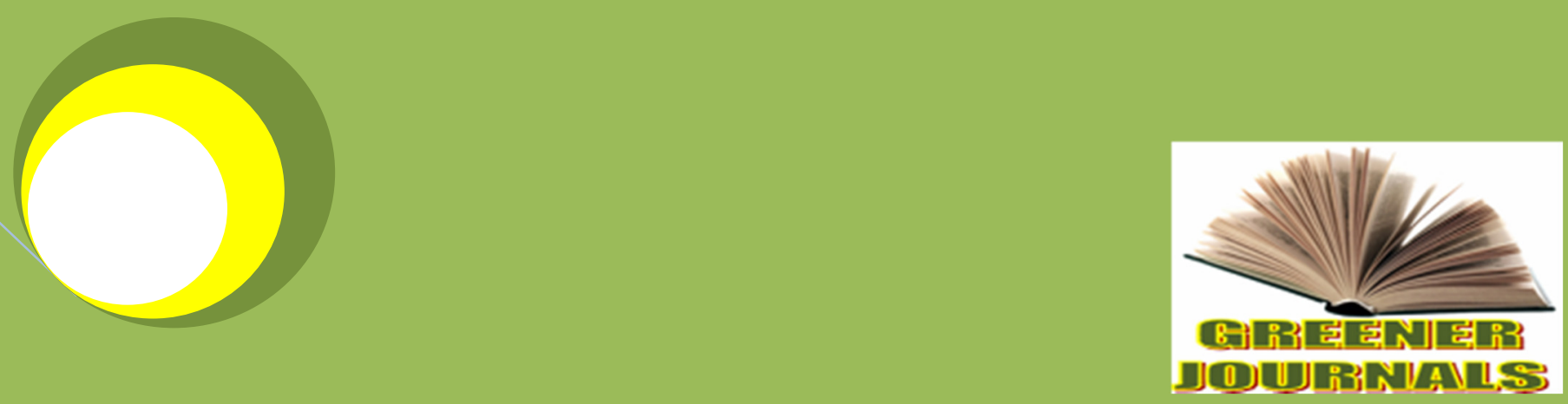

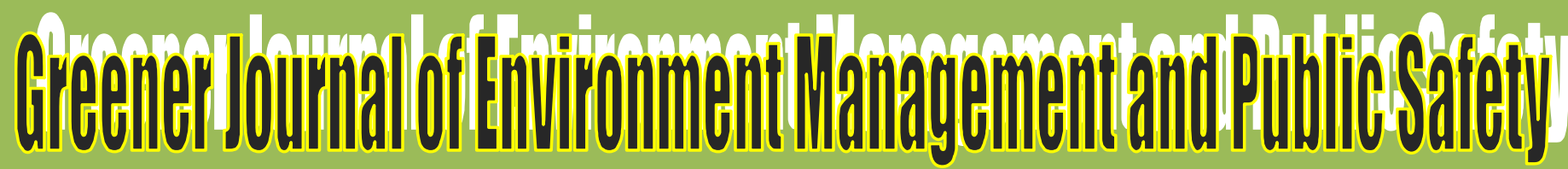
ISSN: 2354-2276

Submitted: $12 / 01 / 2016$ Accepted: 25/01/2016 Published: 07/04/2016

DOI: http://doi.org/10.15580/GJEMPS.2016.2.011216003

Selection of Landfill Site for Waste Disposal Management in Ile Ife, Southwest Nigeria Using Geo- Spatial Technique (Case Study of lle-Ife and its Environs, SouthWest Nigeria)

By

Ogunmola Olaitan Pius 


\title{
Selection of Landfill Site for Waste Disposal Management in Ile Ife, Southwest Nigeria Using Geo- Spatial Technique (Case Study of Ile-Ife and its Environs, South-West Nigeria)
}

\author{
Ogunmola Olaitan Pius
}

\author{
Advanced Space Technology Application Laboratory Southwest, National Space Research and Development \\ Agency, Obafemi Awolowo University Campus, lle Ife. \\ Email: kingskid2k4@yahoo. com, Tel:+2348035858386,+2348057277596.
}

\begin{abstract}
Landfill has been proof to be the easiest and cheapest form for the final disposal of solid waste management in most developing cities in the world, apart from incineration method of solid organic waste that are subjected to combustion. However, landfill design and siting is an extremely difficult operation due to the fact that the process of identification and selection involves strict rules and regulations. Due to the rapid development and population increase experienced so far in lle Ife and environs, proper identification and selection of appropriate sites for landfills need to be taken into consideration and systematic procedures need to be adopted and followed? Environmental degradation occurred many years ago, this is result of wrong dumping of municipal solid waste due tonon availability of landfill site. In this study, attempts have been made to determine sites that are appropriate for landfill siting in Ile Ife and environs, by using geo-spatial technique and such geo-spatial data like land use, drainage, road were obtained from the high resolution geo-eye satellite image. All the data obtained were geo-referenced and digitized through on screen digitizing of the entire road, drainage in the study area, using GIS software (ArcGIS) to process the data, to know the slope, aspects, $500 \mathrm{~m}$ distance of the road to the proposed landfill selected to be appropriate. Suitability of the land was determined from less suitable to the most suitable areas. The final result produced shows the best areas to be the suitable landfill from the map.
\end{abstract}

Keywords: Solid Waste Management, Ile Ife, Geographic Information System (GIS), Landfill Location Criteria, Geo- eye Satellite Image, Geo-spatial, ArcGIS.

\section{$1.1 \quad$ INTRODUCTION}

Waste disposal has been a serious challenge in Nigerian cities especially as rural-urban like lle Ife in Osun state southwest part of Nigeria. The growing environmental and ecological concerns have made the landfill site selection regulations more rigid. The very preliminary step in landfill engineering is the selection of the appropriate location of dumping the hazardous and non hazardous waste materials.

The proper sitting of a landfill takes into account all factors of the surrounding landscape and environment and assures that the landfill is in compliance with the engineering and environmental stipulations. The factors associated with the task of landfill location are more and are essentially of spatial nature. When a huge database of is created for the critical parameters identity, the problem arises how to manage and analyze them.

Geographic Information System (GIS) is a system designed to capture, store, manipulate, analyse, manage and present all types of spatial or geographical data. It is a very good tool for handling a large set of data providing an enabling environment for analysis and display of results with its powerful set of tools for transforming, retrieving, collecting, storing, and displaying spatial data from the real world. The tool could be used to identify the appropriate site location of landfills, through the spatial analysis the issue of solid waste is properly handled through the effective management process of waste reduction, reuse recycle and proper disposal. The growth in population, urbanization, industrialization, and waste generation in the study area calls for proper solid waste management as it has become important for environmental conservation and sustainability. For a sustainable solid waste management system, policies and techniques such as waste recycling, reuse, waste reduction, thermal treatment, land filling etc, must be in place. The landfill method has been widely recognized as the most used of all the waste management techniques. This paper is an eye opener on how to make use of the study that utilizes a geo-spatial technique for the selection of landfill sites in lle Ife. 


\subsection{Literature Review}

The solid waste management system in the town is not effective as wastes are seen dumped on all manner of places including roads, near sensitive areas, and on private properties. It is therefore of importance that solid waste collected are properly disposed at designated sites in the city in order to avoid environmental degradation.

In locating proper sites (Landfills), consideration is giving to environmental factors mainly to avoid environmental risk. Again landfill site should be located far from residential areas and settlement. The site should be away from areas that are susceptible to flooding, as this could result in washout of disposal waste into ground water or stream and would pose risk to human health, the local aquifer and the environment. Other factors relating to land use, roads, slope, wind direction etc are considered in locating a risk free and environmentally friendly waste disposal site. (Babalola and Busu 2011).

The primary data used are topographic maps, geo-eye satellite image data, and geo-spatial data. The acquired data are entered into the GIS environment and processed which then paved way for the actual processing segment. The data were processed using the Arc GIS software. These spatial information and other related factors have been used in identifying and selecting landfill site in lle lfe metropolis.

\section{Flow Chart:}

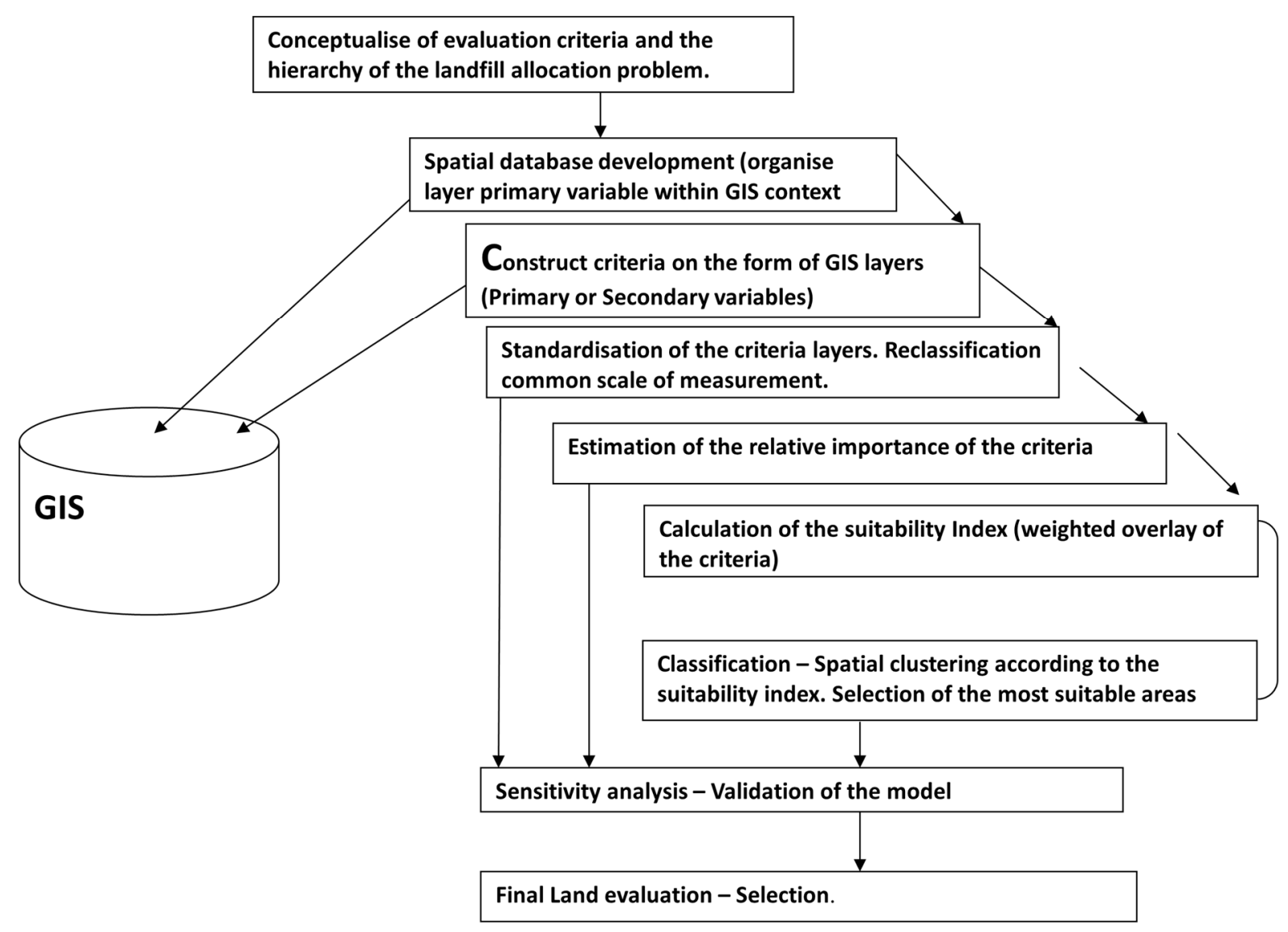

\subsection{MATERIAL AND METHODOLOGY}

\subsection{The Study Area}

The study area is located between latitudes $7^{\circ} 28^{\prime} \mathrm{N}, 4^{\circ} 34^{\prime} \mathrm{E}$ and longitudes $7^{\circ} 46^{\prime} \mathrm{N}, 4^{\circ} 56^{\prime} \mathrm{E}$.lle-lfe and its environs is made up of Ife Central, Ife East, Ife North and Ife South local government. Two out of these local government (Ife Centra land Ife East), arelocatedwithinlle-Ifetownwithapopulationofover1.2million. 


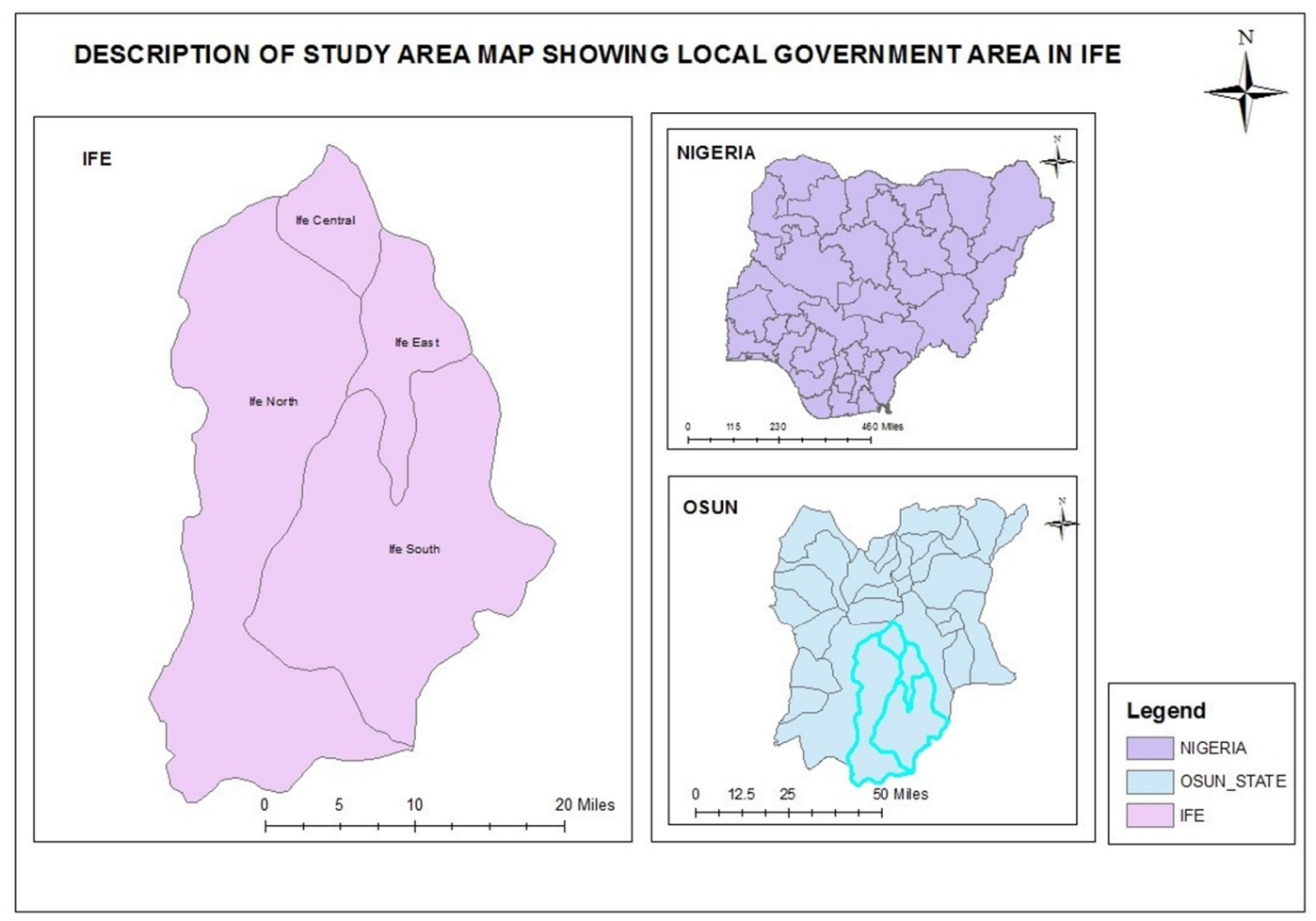

Figure 1: Map of study area showing all the local government areas in lle Ife and Environs

\subsection{Data Collection}

A satellite image (Geo-eye satellite imageries 2011) of lle Ife covering the study area on Scale 1:3000 as well as $1: 100,000$ topographic maps were obtained from the following information layers of the town: the Land use area such as residential areas, settlement, roads, water bodies, groundwater, commercial areas, sensitive areas, recreation, educational institution, agricultural, etc. Others are slope from the contour intervals as extracted from thetopographicmaps. Thegeographicdataandfeaturesrequiredforthepreliminarystageofthestudyextracted using ArcGIS processing software, the primary processing steps are describe below.

The following procedures were used to ascertain needed digital thematic maps:

- Scanning of the primary maps from the laboratory using scanner.

- Ground thrusting and geo-referencing the scanned maps based on the ground coordinates collected during ground trust of the study area.

- On screen digitizing of the primary maps, were done in order to generate the digital the maticmaps, each representing the influencing factor for land fill site selection.

- Locating the global positioning system (GPS) co-ordinates and entering in the data base as latitude and longitude.

- Coordinates are converted into point data and the addition of the attribute data into the desired locations.

\subsection{RESULT AND DISCUSSION}

\subsection{Landfill Location Criteria}

The evaluation criteria considered such as water permeability, depth of the underground water table, and distance from rivers, distance from residential areas, and distance from roads, slope, the land slope, soil characteristics, depth of groundwater, surface water, and religious area, major infra-structural systems (e.g. electric transmission lines, water or sewer pipelines), distance from high way, distance from waste generation source, distance from airport run way were used. However, addition factors to the aforementioned may be considered based on the local conditions and circumstances or may be modified based on the geographic and demographic constraints of the research area. 


\section{Features}

\section{Lake/Pond}

River

Flood Plain

Habitation

Highway

Water Supply well

\section{Criteria}

No landfill within $500 \mathrm{~m}$ of local surface water bodies.

No landfill within $200 \mathrm{~m}$ of river stream.

No landfill within $100 \mathrm{yrs}$ flood plain.

No landfill within $500 \mathrm{~m}$.

No Landfill within $500 \mathrm{~m}$.

No land fill within the radius of $500 \mathrm{~m}$ of any supply well.

Based on established guidelines, and that of Osun state waste management board, state environmental protection agency, and modified according to available data sets for landfill. AGIS-based constraint mapping was employed to eliminate the environmentally unsuitable site and to establish the number of sites for further considerations. However, most of the data and spatial information are in the analogue or hardcopy format, thus requiring scanning and digitizing in order to convert them in to GIS format. Conversion of data layer from vector to raster in order to determine landfill suitability. Reclassification of layer's value was done. Buffering was done on various layers to determine the values to assign as suitable or unsuitable, for instance, pond was buffered by $500 \mathrm{~m}$ and areas within the buffer were as-signed a value of 0 , while areas outside were assigned the value of 1 . Buffer maps generated were overlay in order to identify sites where the constraints parameter will be employed (sites that is not good for landfill).

Analyses through overlaying of various thematic layers which form the set of identified criteria were then performed. Followed by, the evaluation of the composite suitability index scores in the base map. GIS-based constraint mapping approach was done to eliminate areas that are not suitable. Finally, identification of optimized site for landfill using the model was performed.

Point data of the coordinate were used to derive the elevation. Elevations, slope maps, point data of longitude, latitude were processed in GIS environment to produce the contour maps using the surface analysis module of the Arc GIS software. Digital Elevation Model (DEM) was created from the contour which the slope layers were derived. The land use was obtained through interpretation of landsat 2011 satellite image together with a development plan of the study area. Land use of different types were categorised and identified using visual interpretation and then digitized to create land use layers. The land use such as sensitive areas, water body, settlement or built up, commercial areas, agriculture areas, educational areas, high dense areas and medium dense areas.

The road layer was also digitized from the satellite image and categorized into major, minor and other roads. Soil layers were derived from soil map and thereafter over laid to produce the desired composite map.

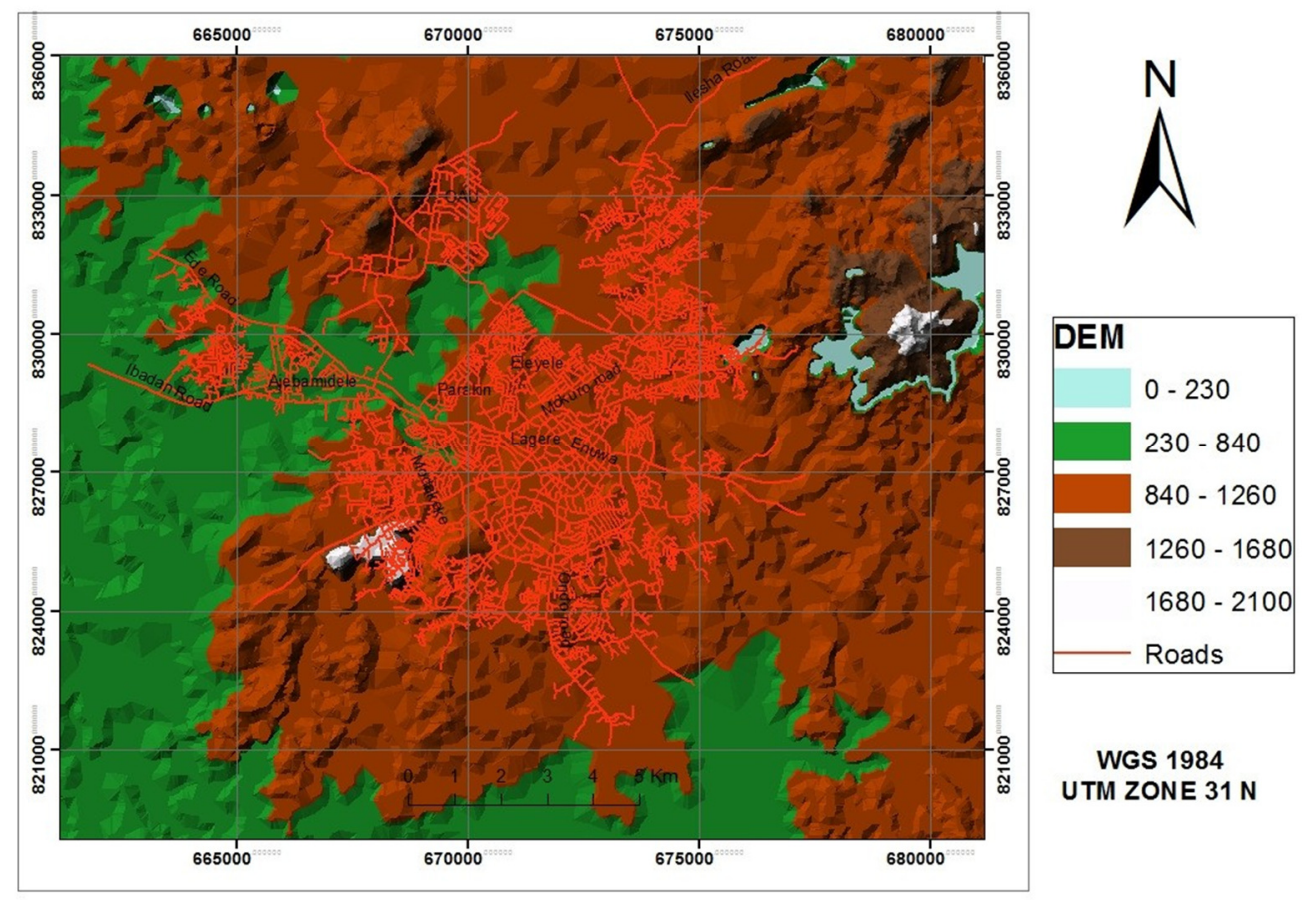

Figure 2: Digital Elevation Model (DEM) 


\subsubsection{Distance from Road Network}

This factor is concerned with the distance from the road network. The road network in the city consists of major roads, minor roads and others. The waste disposal sites should not be too close to the road networks. In deriving the roads layers, on-screen digitizing was performed in order to generate the vector layers and buffer of $600 \mathrm{~m}, 450 \mathrm{~m}$, and 300 $\mathrm{m}$ is applied to the different road networks, and thereafter converted into raster format. Roads within $450 \mathrm{~m}$ were considered not suitable for the siting of landfills. As the distance from the road network increases, suitability also decreases. Areas located farther than $200 \mathrm{~m}$ from the roads were considered to be unsuitable. (Figure 3 ).

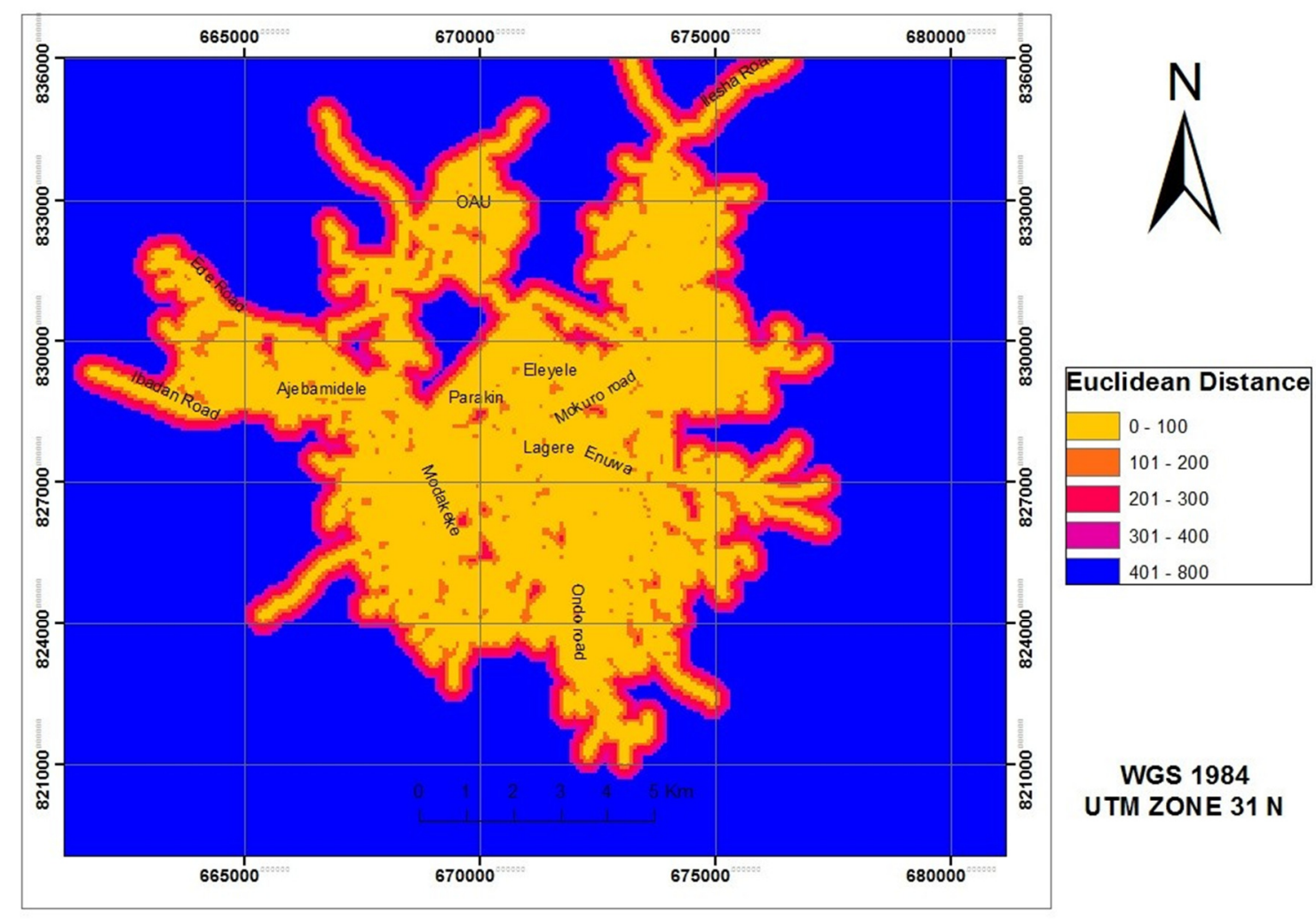

Figure 3: Euclidean Distance 


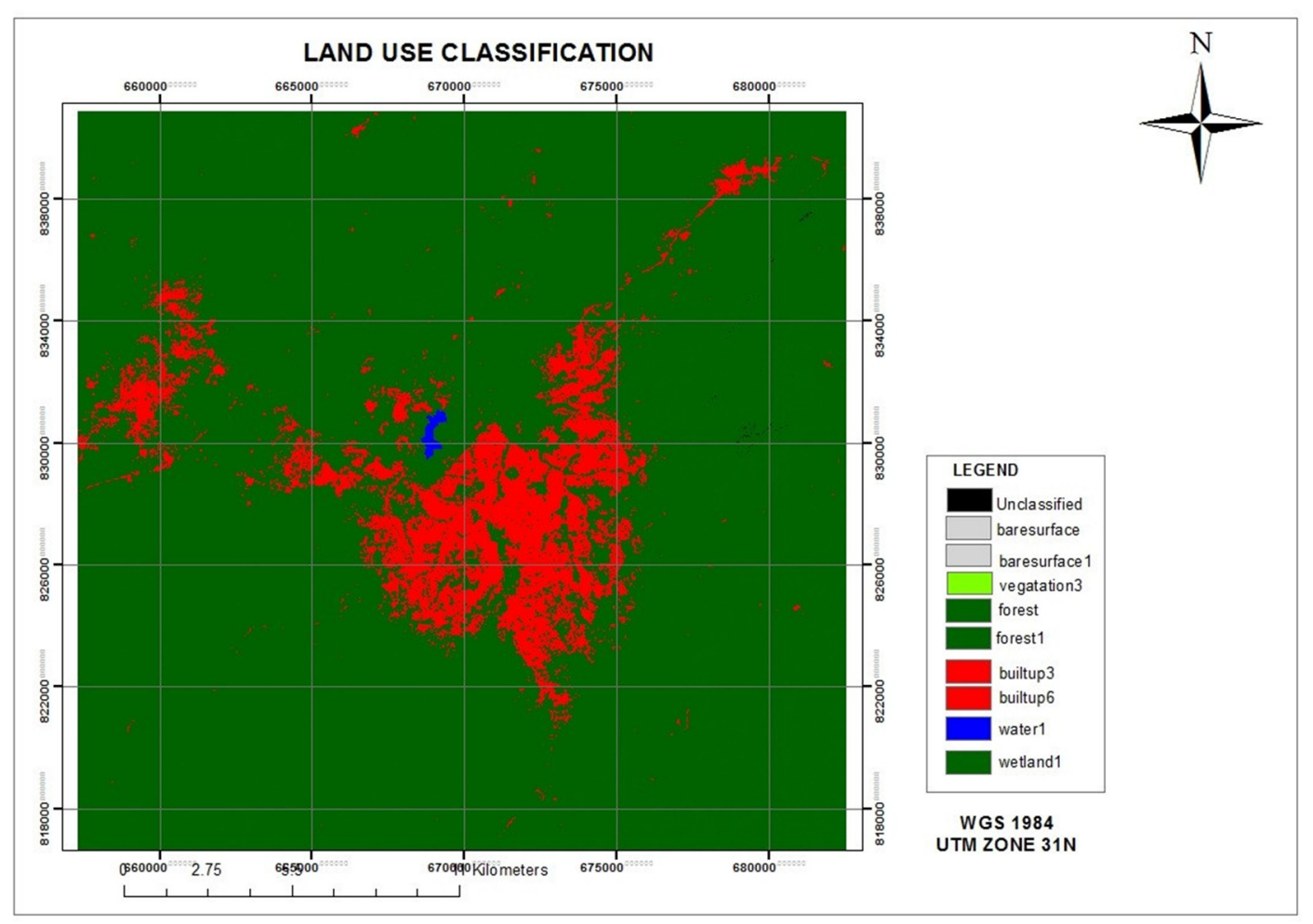

Figure 4: Land use classification

\subsubsection{Surface Water body}

Waste landfill area must not be sited near rivers, lakes, ponds or swamps. Under the Nigerian legislation, it is clearly stated that dumping of solid waste on any water surface, be it a river or lake is prohibited. However, no lake was found anywhere in the study area, hence this criteria was extended to other type of surface water like pond or stream. Hence, water body layer bearing the available pond is digitized and converted into raster format where distance of within 100 $\mathrm{m}$ from the pond was considered unsuitable, and it can be consider suitable when the distance is more than $200 \mathrm{~m}$.

\subsubsection{Elevation Map}

The elevation in this study area ranges between 0 and 30 meters. Elevation is an important parameter in the identification of landfill site. The sites identified to be flat or plain are considered as suitable for landfill siting. The gradingwasbasedontheassumptionthatflatareasarebetterandmoresuitableforlandfillsitingthanareasthat are on a steep.

\subsubsection{Aspect}

Aspect can be defined as the measurement of the direction of slope. It begins with $0^{\circ}$ at the north, and then in a clockwise direction ends at $360^{\circ}$ again at the north. Aspect is often classified into four major directions namely; north, east, south, and west or into eight major directions; northeast, north central, southeast, and southwest.

\subsubsection{Slope}

Slope is the measure of steepness or the degree of inclination of a feature relative to the horizontal plane or rate of change of elevation at a surface location. Slope can be expressed in percent or degree slope. The Triangulated irregular network (TIN) was used to generate slope map. The Triangulated irregular network (TIN) was obtained from the elevation surface values through interpolation using the topographic maps on a scale of 1:100. The areas with high slopes are not ideal for waste disposal, and flat areas are not ideal either. The preferred areas for waste disposal are those with medium slope of not more than $20^{\circ}$. The attribute area of slope has been divided into 3 categories; the first category of $0-10^{\circ}$ represents suitable areas. Second category of $10-20^{\circ}$ represents areas that are less suitable. While the last category represents areas that are above $20^{\circ}$ and are therefore high and unsuitable for landfill. 

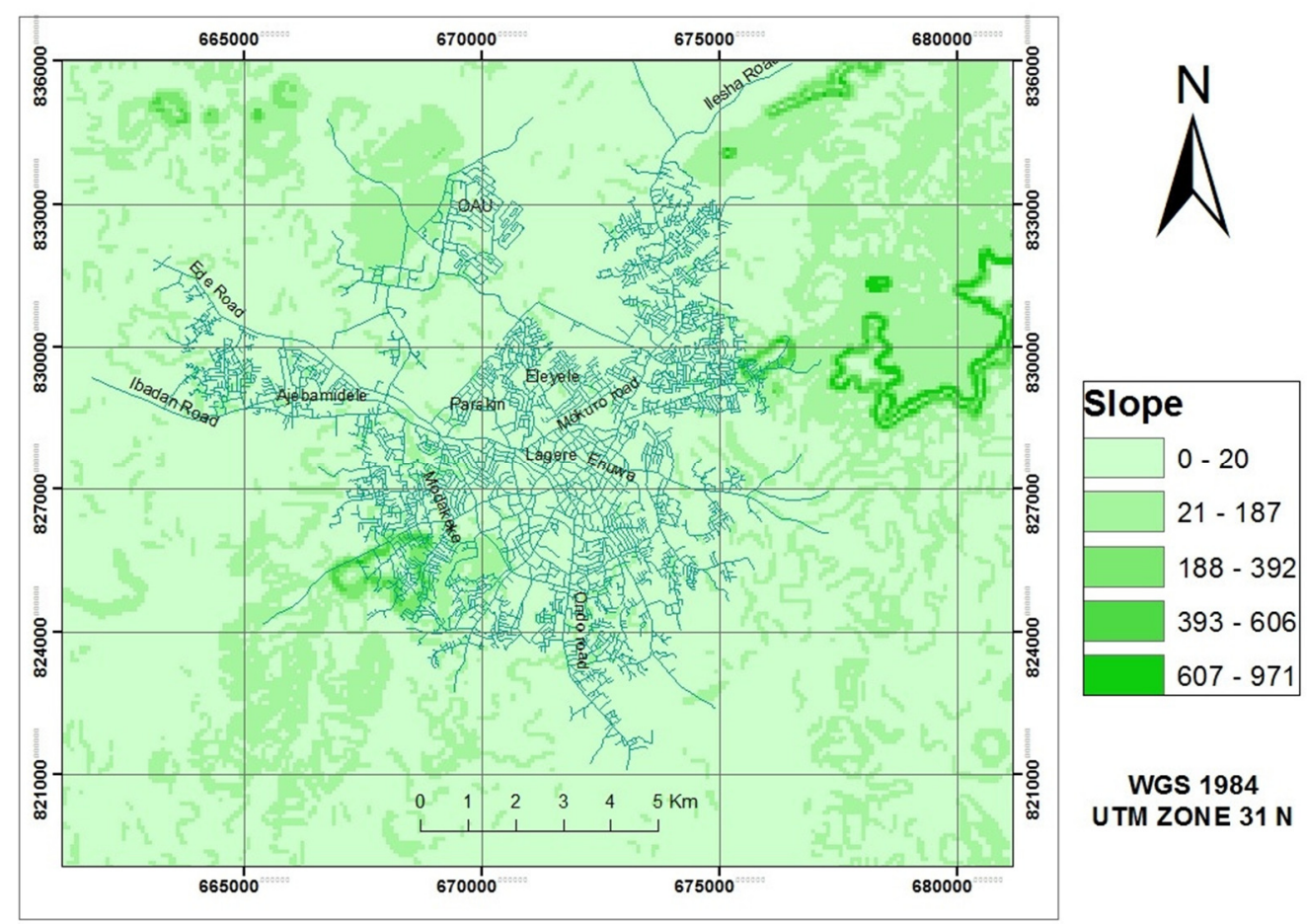

WGS 1984

UTM ZONE $31 \mathrm{~N}$
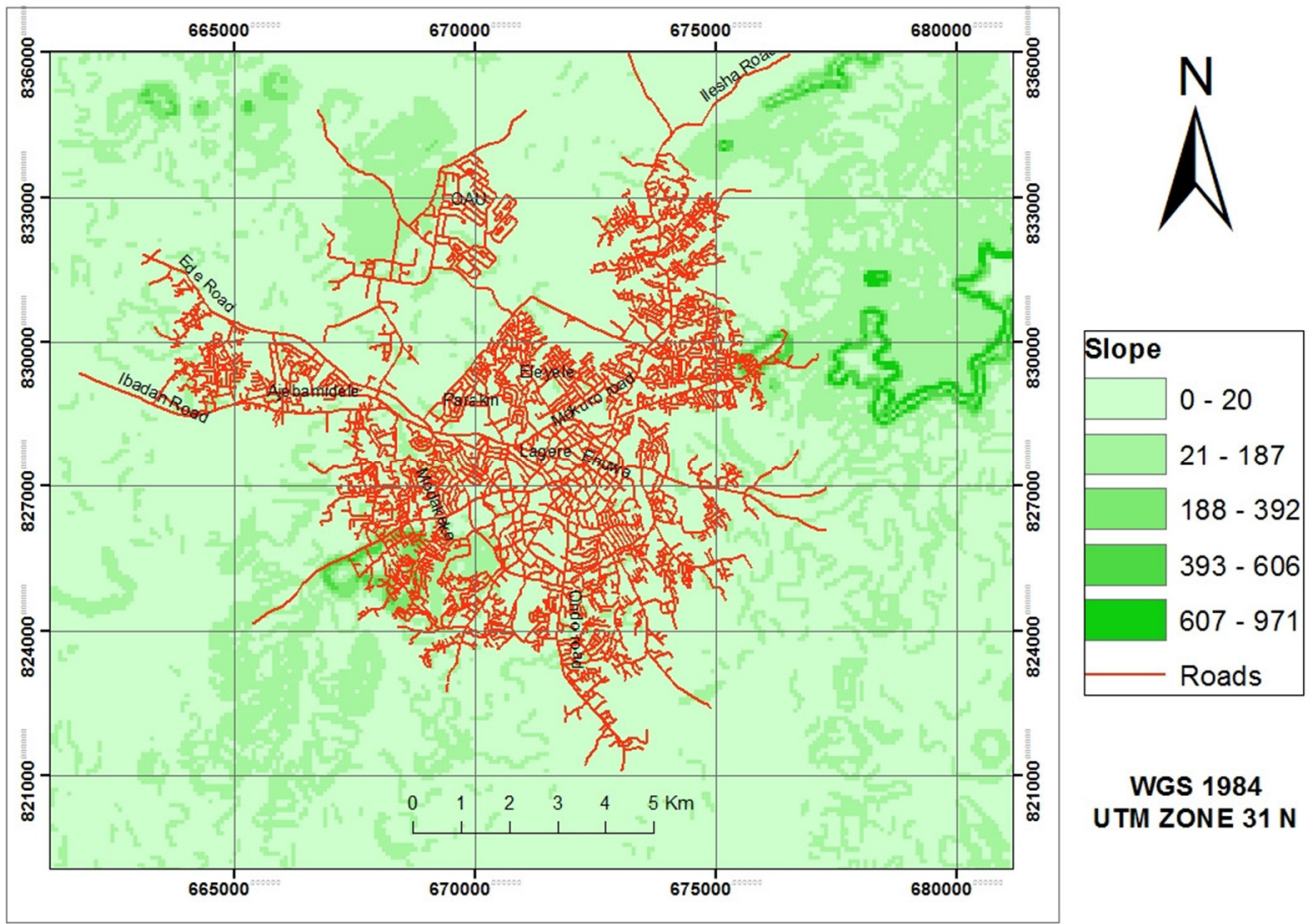

WGS 1984

UTM ZONE $31 \mathrm{~N}$

Fig 5 \& 6: slope

\subsubsection{Road Network Map}

The road network map delineating the national highways and other major roads criss-crossing the town of lle-lfe was prepared. There are federal highways passing through the town: the Akure - Ibadan express road moving along the eastern part of the town, while the lbadan - Ore road at the western part of the town. 


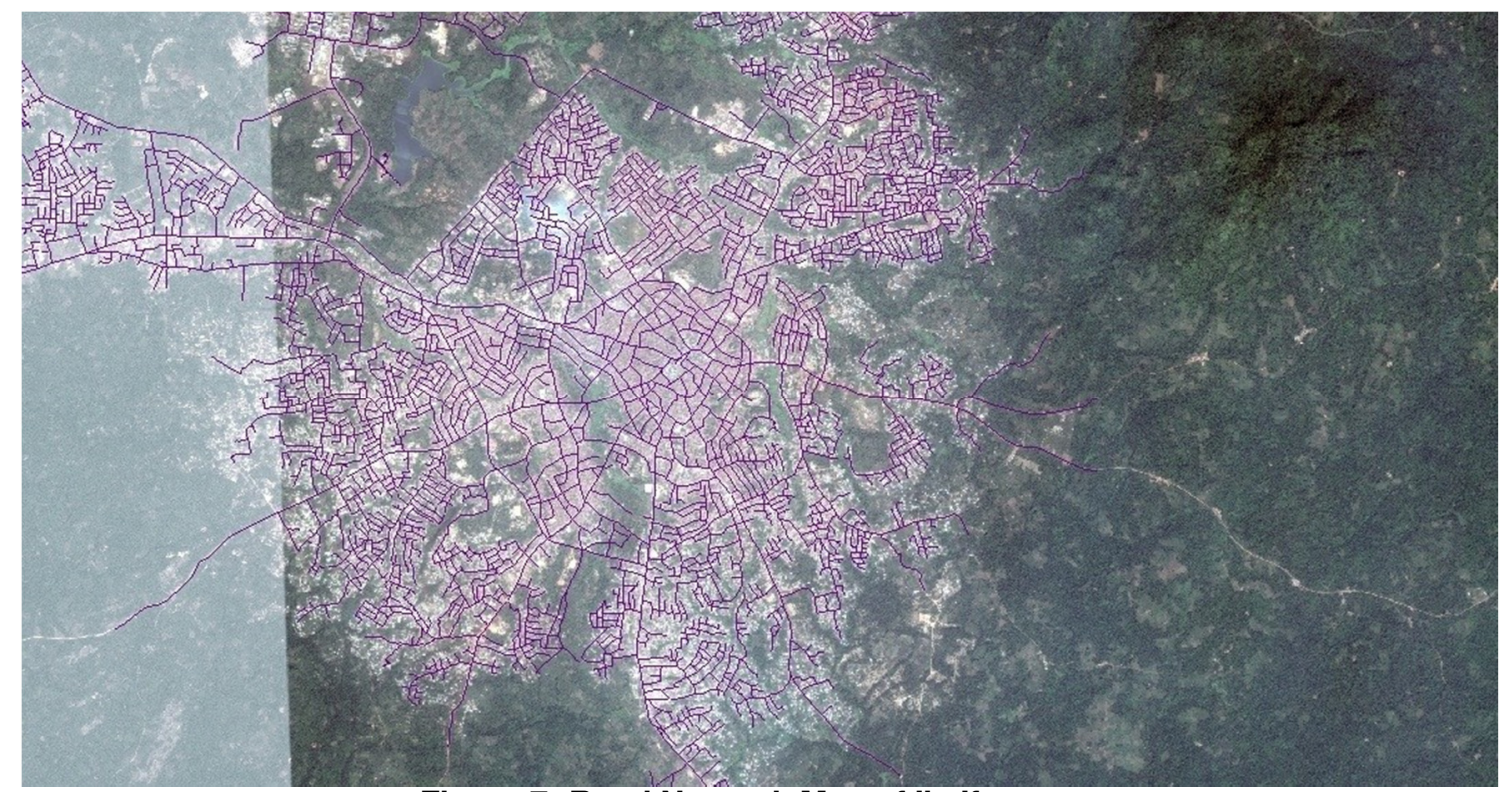

Figure 7: Road Network Map of lle Ife

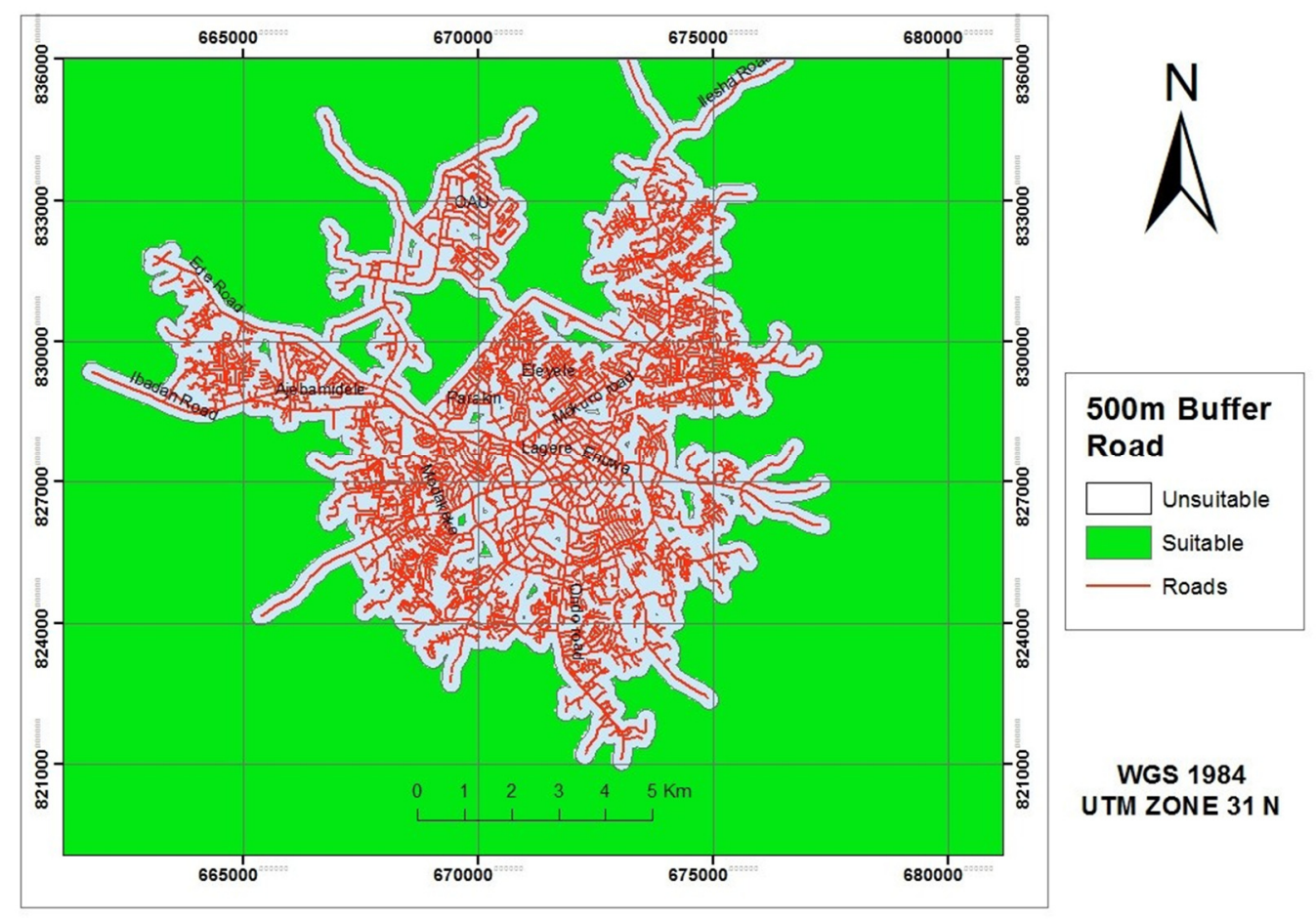

Figure 8: Accessibility (Road) classification

\section{RESULTS AND DISCUSSION}

The study considered the use of decision rules for the location of suitable sites for solid waste disposal, and this has been with reference to research literature, study area criteria as well as multi-criteria evaluation procedure.

A site is considered suitable for the location of solid waste disposal if it fulfils all the requirements or criteria such as; $450 \mathrm{~m}$ from roads, $500 \mathrm{~m}$ from residential, public amenity, agricultural land, administrative offices, and 


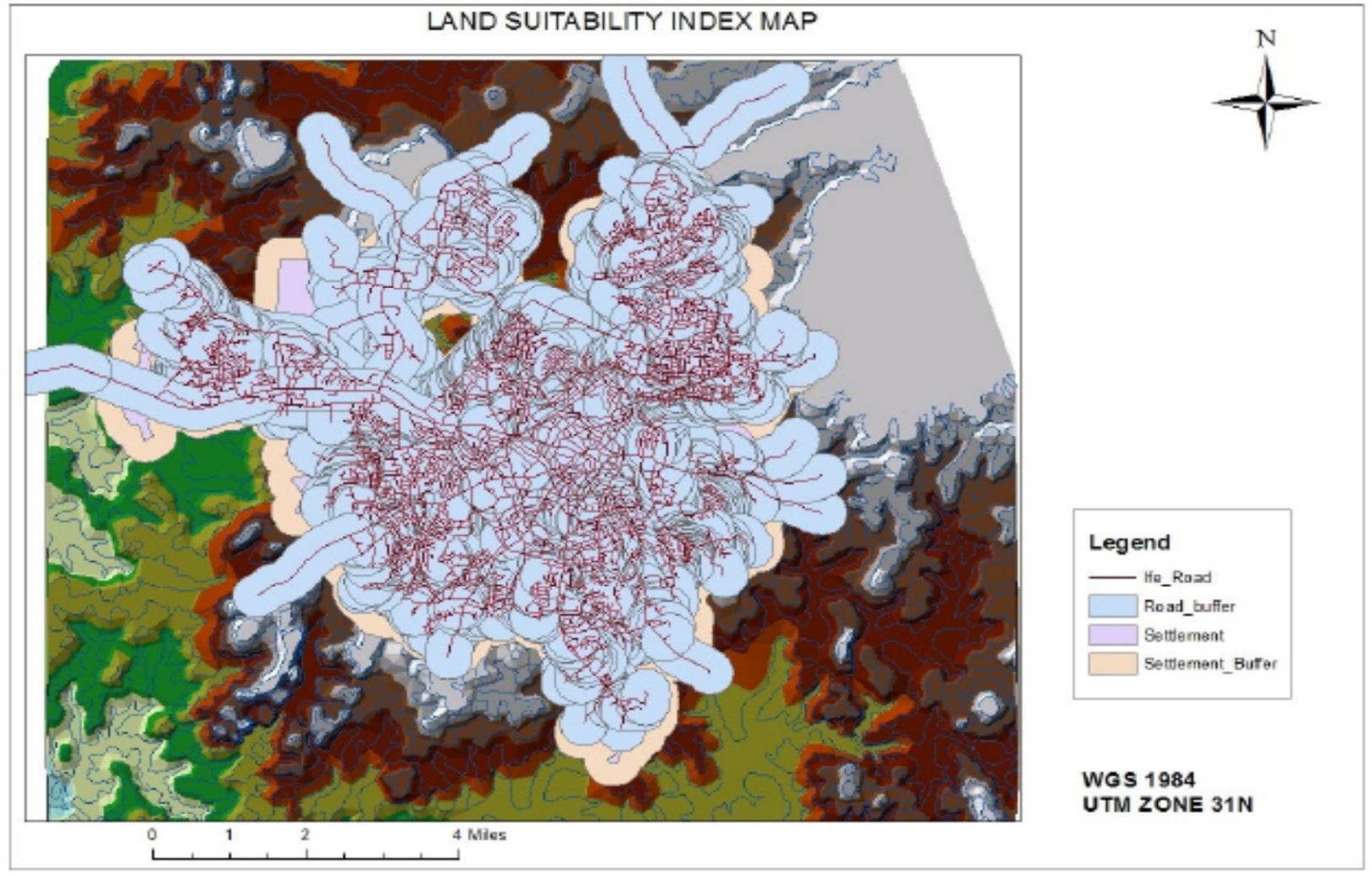

Figure 9: Land Suitability Index map

educational institutions. Others are $200 \mathrm{~m}$ away from recreational and commercial area, $500 \mathrm{~m}$ from sensitive sites. A site is considered less suitable for solid waste disposal if it fulfils all the criteria such as; as $500 \mathrm{~m}$ from roads, $500 \mathrm{~m}$ from residential area, $500 \mathrm{~m}$ from commercial, administrative, educational, and sensitive sites.

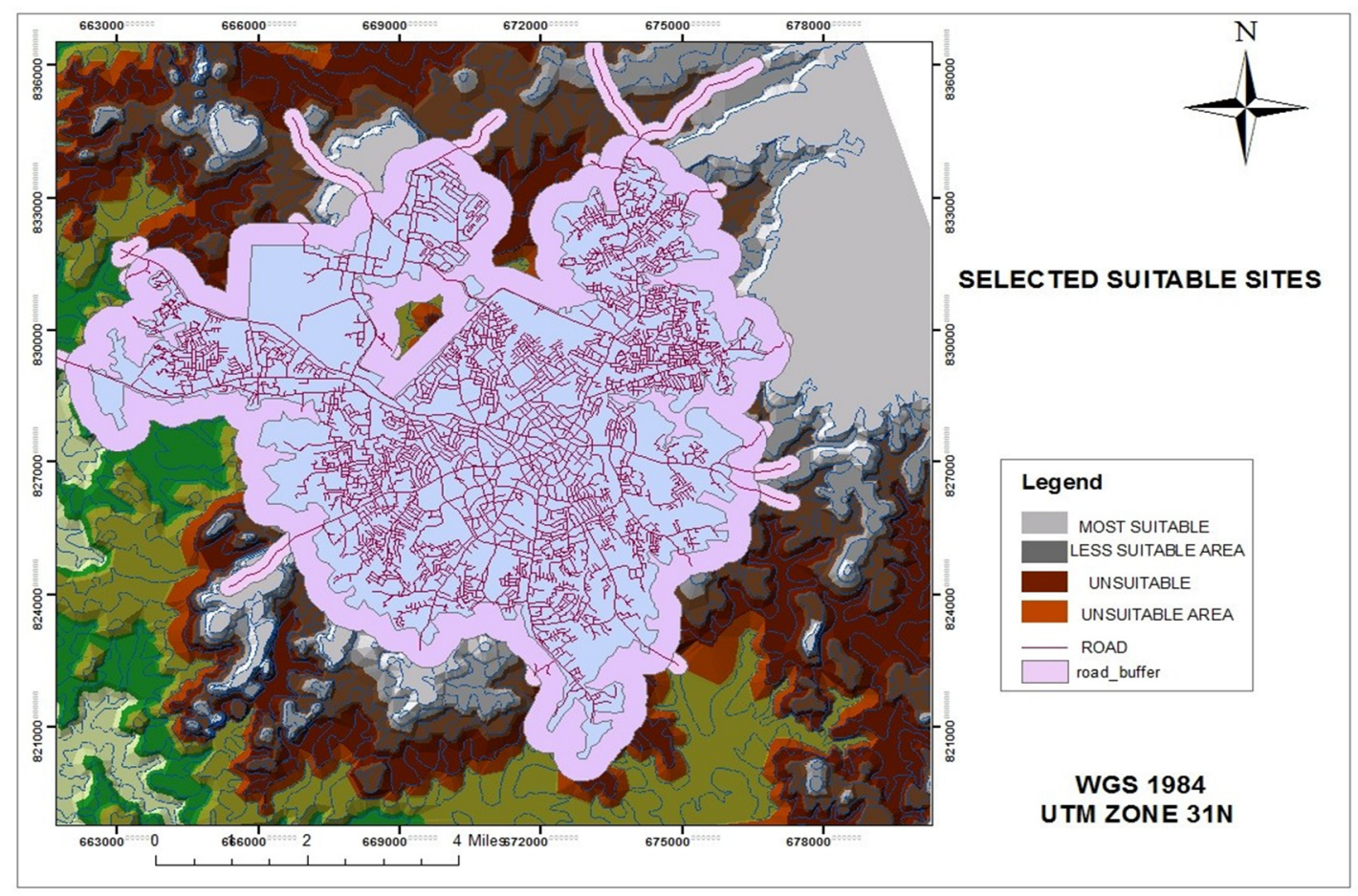

Figure 10: Selected Suitable Site 


\section{CONCLUSIONS}

The methodology employed in this study described the geo-spatial techniques for the selection of suitable sites for the disposal of municipal solid wastes in lle Ife town. The study shows the ability of GIS as a veritable tool for decision support. The techniques considered a number of siting criteria ranging from accessibility, land use, to natural factors which are very important in identifying as well as in locating sites which poses minimum or no risk to the environment. Finally, nine sites were selected for the management of solid waste in the study area. Research makes us to understand that the siting criteria can be boosted based on local constraints, this study considered the available and important criteria. Most of the data available and collected were in the analogue format hence, most of the information was derived using the geo-spatial techniques. The study shows the efficiency of GIS software and can be used by the government and all stakeholders involved in policy making especially in the area of site selection processes for solid waste disposal management in any country.

\section{REFERENCES}

Rao P. J., Brinda V., Rao B. S. and Harikrihna P. (2007).Selection of Landfill Sites for Solid Waste Management in and around Visakhapatnam City-A GIS Approach.Asian Journal of Geoinformatics, Vol. 7, No. 3, pp.35-41.

Rahman M. and Hoque A.(2006). Site Suitability Analysis for Solid Waste Disposal Using GIS: A Case Study on KCC Area. The Journal of Geo-Environment, Vol. 6, pp. 72-86.

Koshy L., Emma P., Sarah L., Tim J. and Kelly B. (2007). Bio-reactive of Leachate from Municipal Solid Waste Assessment of Toxicity," Science of the total Environment, Vol. 384, No. 1-3, pp. 177-181. doi:10.1016/j.scitotenv .2007 .06 .017

Sakai S., Sawe IIS. E., Chandler A.J., Eighmy T.T., Kosson D.S., Vehlow J., Vander Sloot H.A., Hartlen J. and Hjelmar O. (1996). World Trends in Municipal Solid Waste Management. Waste Management, Vol.16, No.5- 6,pp.341350.doi:10.1016/S0956-053X(96)00106-7

Imam A., Mohammed B., Wilson D. C. and Cheese-man C. R. (2008).Solid Waste Management in Abuja, Nigeria.Journal of Waste Management, Vol. 28, No. 2, pp. 468-472.

Olaleye J. B. and Sangodina J. O. (2000). Environmental Protection and Management. Paper Presented at the 32nd Surveyors' Annual General Conference, Nigeria, 2000.

Geo Names(2010).Geographical Database. 2010. Internet Available: http://www.geonames.org/search.html.

Mohan S. and Gandhimathi R. (2009). Solid Waste Characterization and Assessment of the Effect of Dumping Site Leachate on Ground water Quality: A Case Study. Inter-national Journal of Environment and Waste Management, Vol. 3, No. 1-2, pp. 65-77. doi:10.1504/IJEWM.2009.024700

Al-jarrah O. and Abu-Qdais H. (2006).Municipal Solid Waste Landfill Siting Using Intelligent System. Waste Management, Vol. 26, No. 3, 2006, pp. 229-306.

Akbari V., Rajabi M. A., Chavoshi S. H. and Shams R. (2008). Landfill Site Selection by Combining GIS and Fuzzy Multi-Criteria Decision Analysis, Case Study: Bandar Abbas, Iran. World Applied Sciences, Vol. 3, No. 1, pp. 39-47.

Babalola A., Busu I. (2011), "Selection of landfill sites for solid waste treatment in Damaturu town using GIS", "Journal of Environmental Protection", published online www.SciRP.org/journal/jep, page 5-9.

Cite this Article: Ogunmola OP (2016). Selection of Landfill Site for Waste Disposal Management in lle Ife, Southwest Nigeria Using Geo- Spatial Technique (Case Study of lle-Ife and its Environs, South-West Nigeria). Greener Journal of Environmental Management and Public Safety, 5(2):041-050, http://doi.org/10.15580/GJEMPS.2016.2.011216003 